\title{
Adsorption Studies of Radish Leaf Powder
}

\author{
Ankita and Kamlesh Prasad \\ Department of Food Engineering and Technology \\ Sant Longowal Institute of Engineering and Technology, Longowal-148106, Sangrur, INDIA
}

\begin{abstract}
Radish leaves (Raphanus sativus) powder fractions was subjected to moisture adsorption isotherms at different isothermal temperature conditions from $15-45^{\circ} \mathrm{C}$ with an equal interval of $10^{\circ} \mathrm{C}$. The sorption data obtained in gravimetric static method under $0.11-0.90$ water activity conditions were subjected for sorption isotherms and found to be typical sigmoid trend. Experimental data were assessed for the applicability in the prediction through sorption models fitting and found that Polynomial and GAB equations performed well over all fitted models in describing equilibrium moisture content - equilibrium relative humidity (EMC-ERH) relationships for shelf stable dehydrated radish leaf powder, over the entire range of temperatures condition under study. The net isosteric heat of sorption, differential entropy and free energy were determined at different temperatures and their dependence was seen with respect to equilibrium moisture content.
\end{abstract}

\section{Introduction}

Radish leaves are one among the green leafy vegetable category, like several other leafy vegetables which include mustard leaves, fenugreek leaves, spinach leaves, curry leaves and many more. Leaves of radish are green in color which are important source of nutrients (vitamin $\mathrm{C}$, iron, calcium and dietary fibre), even if are being underestimated. Radish plant come under members of the plant family of Brassiceae, earlier termed as Cruciferae or Cabbage which contains many such vegetables of economic importance [1]. This family includes many crops named cabbage, cauliflower, , Brussels sprouts, broccoli, mustard, kale and radish; weed species (shepherd's-purse and wild radish) and cover crop species (yellow mustard, field mustard, black mustard, brown mustard, white mustard, oriental mustard and oilseed radish) [2]. Radish leaves are generally pinnate which form a basal rosette [3]. Radish leaves and roots have been used in various parts of the world to treat cancer and it simultaneously act as antiviral and antimicrobial agents [1]. Radish leaves are rich source of glucosinolates (GSLs) [4, 5]. Myrosinase is the name of the enzyme which has the function to produce isothiocyanates from glucosinolates in the presence of moisture (hydrolysis process) which is responsible for the pungency, odor and hot biting flavor in radish leaves. These play an important role in the prevention of diseases like cancer. The glucosinolates concentration varies with the age of the plant among different portions of the plant $[6,7]$. Glucosinolates are distributed in the seeds, root, stem and leaf of the plant, whereas, the youngest tissues contain their highest proportion [8]. Radishes were very expensive even these were prized above all crops in Greek by the ancient population [9].

Moisture sorption isotherms are of substantial importance to foods for applications particularly to food science and technology such as the designing and optimization of processing as for instance in drying, for ingredient mixing predictions, for assessing the packaging problems and finally for predicting shelf life stability [10]. Its first application is based on an evaluation of the heat of sorption, which describes the interaction between an adsorbent (food matrix) and adsorbate (water molecules). The availability of water in the reactions occuring during food spoilage depends largely on water content and on the properties of the diffusion surface, thus, are based on the thermodynamic function of sorbed water. Sorption isotherms have been used to estimate the thermodynamic functions of several food materials [11], which comprises differential enthalpy (also termed as heat of sorption), differential entropy and free energy. Moreover, these thermodynamic parameters are useful for defining appropriate packaging materials in maintaining sensory attributes and nutrition of the desired food material [12].

\section{Materials and Methods}

\subsection{Sample preparation}


Powder obtained from dried radish leaves using improved technique $\left(80^{\circ} \mathrm{C}-70^{\circ} \mathrm{C}\right)$ maintained in cabinet drier [13] was taken for adsorption studies. Flow diagram showing the preparation of radish leaf powder as reported in figure 1. Further, the obtained powder after size reduction using laboratory grinder is classified into mix and fine fractions by using sieve of 60 mesh (resulting maximum $250 \mu \mathrm{m}$ size particles) [14]. The dried powder samples were packed in the dark glass jars and kept inside refrigerator at $4 \pm 2{ }^{\circ} \mathrm{C}$ for at least 5 days to equilibrate the moisture distribution if any.

Radish leaves (Radish F1 Hybrid NBH-White Queen)<smiles>C1CCCC1</smiles>

Dehydration in cabinet drier at $80^{\circ} \mathrm{C}$ and $70^{\circ} \mathrm{C}$<smiles>OC1(C2CCCC2)C2CCC(CC2)C1[Si]</smiles>

Sieving using 60 BSS (250 $\mu \mathrm{m}$ particle size $)$

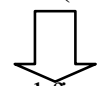

Adsorption studies on mix and fine radish leaf powder fractions

Figure 1. Flow diagram showing preparation of radish powder

\subsection{Adsorption isotherm}

The static method of sorption isotherm was used to represent the relation between equilibrium moisture content (EMC) of the representative dehydrated radish leaf powder with the equilibrium relative humidity (ERH) of the surrounding environment at a particular temperature. Saturated salt solutions were made and excess of solid salt was added more to make sure that solutions remain saturated. To establish moisture adsorption isotherms, the equilibrium moisture contents were plotted with respect to surrounding's relative humidity values $(\mathrm{ERH})$ maintained at $11.1,22.9,32.9,43.9,51.8,64.8,75.5$ and 86.5 (using lithium chloride, potassium acetate, magnesium chloride, potassium carbonate, potassium nitrite, sodium dichromate, sodium chloride, and potassium chromate) at four different temperatures $\left(15^{\circ} \mathrm{C}, 25^{\circ} \mathrm{C}, 35^{\circ} \mathrm{C}\right.$ and $45^{\circ} \mathrm{C}$ ) (using Winks weight equilibrium method) [15]. A tripod was also placed in each jar. The accurately weighed dehydrated samples (5.0 $\pm 0.001 \mathrm{~g}$ ) were placed on petriplates and inserted in the desiccators having specific saturated salt solutions for sorption studies. The readings were noted at regular interval of 48 hours. The experiment was considered done when three consecutive weight measurements showed a difference of less than $0.001 \mathrm{~g}$.

The adsorption curves describes the hygroscopic equilibrium of a given food product. These equilibrium (adsorption) curves are determined by the saturated salt solutions method. Another application of the adsorption isotherms is in the determination of the drying time of hygroscopic substances [16]. Moreover, these isotherms convey important information to other processes which include packaging and storage [17]. The selected equations are described in table 1 , where $\mathrm{M}$ denotes the m.c. (dry basis) and $\mathrm{a}_{\mathrm{w}}$ is water activity [18].

\subsection{Model fitting}

The coefficients of various available sorption models were applied using standard non-linear regression technique. Not a single equation has been found to accurately depict the behaviour of adsorption isotherms of all types of foods in the entire range of water activity. For example, BET equation allows one to examine the fixation phenomenon alongwith liberation process of water molecules. Other models, such as Polynomial model, Hailwood and Horbin model and Smith model exhibits consistencies for a wide variety of vegetable products. Hailwood and Horbin model is equivalent to the $\mathrm{GAB}$ equation at constant temperature. Most of the sorption models are two or three parameter model comprising $\mathrm{a}, \mathrm{b}$ and $\mathrm{c}$ as unknown parameters to be estimated $[18,19,20]$.

\subsection{Validation of sorption models}

The coefficients of various sorption equations (table 1) were determined by means of standard non-linear regression technique using statistica software version 7 . The various sorption models (table 2, 3) were evaluated for their suitability in predicting the adsorption behaviour of the sample on the basis of few important parameters. Correlation coefficient $\left(\mathrm{R}^{2}\right)$ was evaluated as it is considered as most important criterion for selecting the best equation to define the curves of radish leaf powder. In addition to $\mathrm{R}^{2}$, other statistical parameters include $\mathrm{E} \%$ values which was used to determine the goodness of fit of different models. The average percent difference between the experimental and predicted values mean relative deviation modulus, E\%, defined by the mentioned equations.

\subsection{Thermodynamic functions}

The isosteric heats of sorption were calculated at several moisture levels from the slopes of the isosteres of the natural logarithms of a, versus the reciprocal absolute temperature. The slope of the line decreases to zero as moisture content increases, which is indicative of reduced water interactions, i.e., less binding energy [21]. The net isosteric heat $\mathrm{q}_{\mathrm{st}}$ is defined as the total heat of sorption $\left(\mathrm{Q}_{\mathrm{st}}\right)$ in the food minus the heat of vaporization $(\Delta \mathrm{Hv})$ of water, at the system temperature. The heat of adsorption is the index of the energy released on adsorption [11].

Using relationship between the isosteric heat $\left(\Delta \mathrm{H}_{\mathrm{d}}\right)$ and the differential entropy $\left(\Delta \mathrm{S}_{\mathrm{d}}\right)$ of sorption energy values can be determined as :

$$
\left(-\ln \mathrm{a}_{\mathrm{W}}\right)_{\mathrm{M}}=\Delta \mathrm{H}_{\mathrm{d}}\left(\frac{1}{\mathrm{RT}}\right)
$$


By plotting $\ln \left(\mathrm{a}_{\mathrm{w}}\right)$ versus $1 / \mathrm{T}$, for a given moisture content (M), $\Delta \mathrm{H}_{\mathrm{d}}$ was determined from the slope $\left(-\Delta \mathrm{H}_{\mathrm{d}} / \mathrm{R}\right)$ as that from clausius clapreyon equation, and $\Delta \mathrm{S}_{\mathrm{d}}$ from the intercept $\left(\Delta \mathrm{S}_{\mathrm{d}} / \mathrm{R}\right)$.

\section{Results and Discussion}

\subsection{Adsorption isotherm behavior}

The experimental adsorption data for green radish leaf powder for mix and fine fractions at different temperatures are plotted with experimental and empirical results from Polynomial and GAB equation in figure 2 and figure 3 respectively as per fitting criteria of lower $\mathrm{E} \%$ and higher $\mathrm{R}^{2}$. This behavior of variation of moisture content with respect to temperature may be explained by considering excitation states of molecules. At elevated temperatures, water molecules are in an increased state of excitation, thus decreasing the attractive forces between them. This tends to a decrease in the degree of water sorption by food material at a particular relative humidity with the increase in temperature [10]. Activation of the water vapor molecules because of increasing temperature levels causes them to break away from the water binding (adsorbent) sites, thus responsible for lowering the equilibrium moisture content. This result may be justified by considering the higher excitation (unstable) state of water molecules at higher temperature and becoming unstable, thus decreasing the attractive forces between them [22]. Sorption isotherms shows that radish leaf powder at low water activity levels retained small amounts of water and amount of water increases as the water activity levels rises. The sorption isotherms of radish leaf showed the typical sigmoid shape of Type II or III, according to the BET classification. The related shapes of sorption isotherm are well documented in literature for most of the food materials [22, 23].

On the other hand, the EMC increases with increasing ERH at a constant temperature level. Similar results have been discussed in the literature for the sorption curves [23, $25]$. Water activity of about 0.30 , where water is held on polar active sites of relatively high energies. This is termed as the monolayer. The water activity in the range of 0.30 0.70 is termed as multilayer water. It consists of water layers, which are adsorbed and got stuck onto the first layer by hydrogen bonds. Water activity of 0.7 and above, where the water approaches the condition of condensed or free water and the isotherm reflects solution and surface capillary effects [20]. Monolayer moisture contents $\left(\mathrm{m}_{0}\right)$, was obtained using GAB and BET equations, are also given in table 2. The $\mathrm{m}_{0}$ values were important for determination of the storage conditions and controlling the possible deterioration reactions. The $\mathrm{m}_{0}$ values of radish leaf were decreased with increasing temperature [24].

\subsection{Fitting of sorption models to experimental adsorption findings}

The sorption curve for radish leaf is drawn as EMC against aw $(\mathrm{ERH} / 100)$. These curves are used to estimate the coefficients of the different sorption models and it was found that Smith, Polynomial, BET, Hailwood Horbin and GAB equations gave best fit to the experimental data for instant radish leaf powder with not only highest values of $\mathrm{R}^{2}$ and least values of $\mathrm{E} \%$ for adsorption isotherms for a wide range of water activity. List of various mathematical model equations are presented in table 1 .

$\mathrm{R}^{2}$ values for radish powder (mix fractions) ranged from 0.985 to 0.996 for GAB model and 0.985 to 0.996 for Hailwood and Horbin, followed by Smith (0.983 to 0.992) followed by polynomial ( 0.966 to 0.995$)$ followed by BET (0.866 to 0.938$)$ and best model fitting was observed in case of Hailwood and Horbin and GAB model. Also, E\% values are lower in case of GAB $(0.408$ to $7.830 \%)$, Hailwood and Horbin $(0.408$ to 7.831$)$, BET $(0.432$ to $15.645 \%)$, Smith (0.376 to $10.992 \%)$, Polynomial (0.733 to 7.033$)$. Data reveals all the fitted models are resulting E\% values less than $5 \%$, which is the criteria for better fitting except BET model. This is a limiting factor, because suitability of BET equation at $\mathrm{a}_{\mathrm{w}}$ less than $0.5 . \mathrm{R}^{2}$ values for radish powder (fine fractions) ranged from Polynomial (0.930 to 0.998) Also, E\% values are lowest in case of Polynomial model $(0.020$ to $1.911 \%)$. Whereas, other fitted models are not showing better fit according to the selected criteria based on higher $\mathrm{R}^{2}$ and lower E\% values. This shows, polynomial model is resulting $E \%$ values less than $5 \%$ and $R^{2}$ value approaching to unity, which is the criteria for better fitting.

Among various fitted models on experimental data, the appropriate models are given in table 2 and table 3 . Monolayer moisture contents $\left(\mathrm{m}_{0}\right)$, obtained using GAB and BET equations are determined. The $\mathrm{m}_{0}$ values are of big importance for determination of the storage conditions and minimizing the possible deterioration reactions. The $\mathrm{m}_{0}$ values of radish leaf were decreased with increasing temperature [24].

\subsection{Thermodynamic parameters}

The study of sorption isotherms at least at two different temperatures gives thermodynamic data on isosteric heat of sorption with the use of mentioned Clausius-Clapeyron equation. The isosteric heat of adsorption changes with the change in amount of moisture adsorbed by the radish leaf powder (substrate). The relationship between isosteric heat of sorption (differential enthalpy) and equilibrium moisture content of radish leaf powder (fine fractions and mix fractions) is plotted in figure 4 . The heat of adsorption also termed as differential enthalpy is a function of energy released on sorption. Thus, the heat of adsorption is considered as indicative of the binding forces between the sorption sites (adsorbent) and the water vapour (adsorbate) [26]. 
Table 1. Mathematical models (1-2-3 parameter equations) for adsorption isotherm

\begin{tabular}{lcc}
$\begin{array}{l}\text { Sr. } \\
\text { No. }\end{array}$ & Model equation & Model name \\
\hline 1. & $\mathrm{M}=\mathrm{a}+\mathrm{b} \ln (1-\mathrm{aw})$ & Smith \\
2. & $\mathrm{M}=\frac{C a_{w} m_{o}}{\left(1-a_{w}\right)\left(1-a_{w}+C a_{w}\right)}$ & BET \\
3. & $\mathrm{M}=\left(\frac{1}{\mathrm{a}+\mathrm{b} a_{w}+\frac{\mathrm{c}}{\mathrm{a}_{\mathrm{w}}}}\right)$ & $\begin{array}{c}\text { Hailwood } \\
\text { and Horbin }\end{array}$ \\
4. & $\mathrm{M}=\mathrm{a}+\mathrm{b} \mathrm{a}_{\mathrm{w}}+\mathrm{c} \mathrm{a}_{w}{ }^{2}$ & Polynomial \\
5. & $\left.\mathrm{M}=\frac{\text { GAB }}{\left(1-k a_{w} m_{o}\right.}\right)\left(1-k a_{w}+C k a_{w}\right)$ & \\
\hline
\end{tabular}

where, $\mathrm{M}$ - equilibrium moisture content (\%, d.w.b.); $\mathrm{a}_{\mathrm{w}}$ - water activity; $\mathrm{a}, \mathrm{b}$ and $\mathrm{c}$ are model parameters to be estimated

Table 2. Model constants and coefficients with statistical parameters for radish powder mix fraction

\begin{tabular}{|c|c|c|c|c|}
\hline \multirow[t]{2}{*}{$\begin{array}{l}\text { Model } \\
\text { no. }\end{array}$} & \multirow[t]{2}{*}{$\begin{array}{l}\text { Tem } \\
\text { p } \\
\left({ }^{\circ} \mathrm{C}\right)\end{array}$} & \multirow[t]{2}{*}{$\begin{array}{l}\text { Model constants } \\
\text { and coefficients }\end{array}$} & \multicolumn{2}{|c|}{$\begin{array}{l}\text { Statistical } \\
\text { parameter }\end{array}$} \\
\hline & & & $\mathbf{R}^{2}$ & E\% \\
\hline \multirow[t]{4}{*}{ BET } & 15 & $\mathrm{~m}_{0}: 3.937, \mathrm{c}: 59.292$ & 0.938 & 1.139 \\
\hline & 25 & $\begin{array}{c}\mathrm{m}_{0}: 3.003, \\
\mathrm{c}: 455.2692\end{array}$ & 0.879 & 0.937 \\
\hline & 35 & $\mathrm{~m}_{0}: 2.486, \mathrm{c}: 134.898$ & 0.866 & 0.432 \\
\hline & 45 & $\mathrm{~m}_{0}: 2.101, \mathrm{c}: 34.421$ & 0.890 & $\begin{array}{c}15.64 \\
5\end{array}$ \\
\hline \multirow{4}{*}{$\begin{array}{l}\text { Hailwo } \\
\text { od and } \\
\text { Horbi } \\
\text { n }\end{array}$} & 15 & $\begin{array}{c}\mathrm{a}: 0.091, \mathrm{~b}:-0.109 \\
\mathrm{c}: 0.035\end{array}$ & 0.985 & 1.542 \\
\hline & 25 & $\begin{array}{c}\mathrm{a}: 0.053, \mathrm{~b}:-0.076 \\
\mathrm{c}: 0.056\end{array}$ & 0.995 & 0.408 \\
\hline & 35 & $\begin{array}{c}\mathrm{a}:-0.017, \mathrm{~b}:-0.056, \\
\mathrm{c}: 0.082\end{array}$ & 0.996 & 1.125 \\
\hline & 45 & $\begin{array}{c}\mathrm{a}: 0.035, \mathrm{~b}:-0.086 \\
\mathrm{c}: 0.099\end{array}$ & 0.987 & 7.831 \\
\hline \multirow[t]{4}{*}{$\begin{array}{l}\text { Polyno } \\
\text { mial }\end{array}$} & 15 & $\begin{array}{c}\mathrm{a}:-5.987, \mathrm{~b}: 35.703, \\
\mathrm{c}: 3.445\end{array}$ & 0.966 & 1.411 \\
\hline & 25 & $\begin{array}{c}\mathrm{a}:-0.113, \mathrm{~b}: 0.003 \\
\mathrm{c}: 3.601\end{array}$ & 0.989 & 2.047 \\
\hline & 35 & $\begin{array}{c}\mathrm{a}: 1.353, \mathrm{~b}: 16.867 \\
\mathrm{c}: 1.354\end{array}$ & 0.995 & 0.733 \\
\hline & 45 & $\begin{array}{c}\mathrm{a}: 2.482, \mathrm{~b}: 13.668, \\
\mathrm{c}: 0.697\end{array}$ & 0.981 & 7.033 \\
\hline \multirow[t]{3}{*}{ GAB } & 15 & $\begin{array}{c}\mathrm{c}: 4.9116, \mathrm{k}: 0.888 \\
\mathrm{~m}_{0}: 6.508\end{array}$ & 0.985 & 1.541 \\
\hline & 25 & $\begin{array}{c}\mathrm{c}: 3.200, \mathrm{k}: 0.784 \\
\mathrm{~m}_{0}: 7.121\end{array}$ & 0.995 & 0.408 \\
\hline & 35 & $\mathrm{c}: 2.288, \mathrm{k}: 0.730$ & 0.996 & 1.125 \\
\hline
\end{tabular}

\begin{tabular}{|c|c|c|c|c|}
\hline \multicolumn{5}{|c|}{$\mathrm{m}_{0}: 7.328$} \\
\hline & 45 & $\begin{array}{c}\mathrm{c}: 2.451, \mathrm{k}: 0.777 \\
\mathrm{~m}_{0}: 5.325\end{array}$ & 0.994 & 7.830 \\
\hline \multirow[t]{4}{*}{ Smith } & 15 & $\mathrm{a}: 0.971, \mathrm{~b}:-5.391$ & 0.983 & 0.376 \\
\hline & 25 & $\mathrm{a}: 1.308, \mathrm{~b}:-3.979$ & 0.992 & 2.737 \\
\hline & 35 & $\mathrm{a}: 0.986, \mathrm{~b}:-3.327$ & 0.992 & 0.421 \\
\hline & 45 & $\mathrm{a}: 0.536, \mathrm{~b}:-2.881$ & 0.991 & $\begin{array}{c}10.99 \\
2\end{array}$ \\
\hline
\end{tabular}

Table 3. Model constants and coefficients with statistical parameters for radish powder fine fraction

\begin{tabular}{|c|c|c|c|c|}
\hline \multirow[t]{2}{*}{ Model no. } & \multirow{2}{*}{$\begin{array}{l}\text { Te } \\
\text { mp } \\
\left({ }^{\circ} \mathrm{C}\right. \\
)\end{array}$} & \multirow[t]{2}{*}{$\begin{array}{l}\text { Model constants } \\
\text { and coefficients }\end{array}$} & \multicolumn{2}{|c|}{$\begin{array}{l}\text { Statistical } \\
\text { parameter } \\
\mathrm{S}\end{array}$} \\
\hline & & & $\mathbf{R}^{2}$ & E\% \\
\hline \multirow[t]{4}{*}{ BET } & 15 & $\mathrm{~m}_{0}: 4.875, \mathrm{c}: 0.023$ & 0.580 & 27.821 \\
\hline & 25 & $\mathrm{~m}_{0}: 3.238, \mathrm{c}: 0.022$ & 0.570 & 16.169 \\
\hline & 35 & $\mathrm{~m}_{0}: 5.137, \mathrm{c}: 0.014$ & 0.500 & 9.281 \\
\hline & 45 & $\mathrm{~m}_{0}: 4.132, \mathrm{c}: 0.013$ & 0.630 & 8.959 \\
\hline \multirow[t]{4}{*}{$\begin{array}{l}\text { Hailwood } \\
\text { and Horbin }\end{array}$} & 15 & $\begin{array}{c}\mathrm{a}: 0.260, \mathrm{~b}:-0.003 \\
\mathrm{c}: 0.077\end{array}$ & 0.942 & 0.069 \\
\hline & 25 & $\begin{array}{c}\mathrm{a}:-297.410 \\
\mathrm{~b}: 47.080, \mathrm{c}:- \\
2495.300\end{array}$ & 0.380 & 87.483 \\
\hline & 35 & $\begin{array}{c}\mathrm{a}:-228.360 \\
\mathrm{~b}: 37.490, \mathrm{c}:- \\
2078.350\end{array}$ & 0.900 & 87.482 \\
\hline & 45 & $\begin{array}{c}\mathrm{a}:-217.750, \\
\mathrm{~b}: 36.990, \mathrm{c}:- \\
2134.020\end{array}$ & 0.640 & 87.478 \\
\hline \multirow[t]{4}{*}{ Polynomial } & 15 & $\begin{array}{c}\mathrm{a}:-0.375, \mathrm{~b}: 0.007 \\
\mathrm{c}: 9.092\end{array}$ & 0.930 & 0.358 \\
\hline & 25 & $\begin{array}{c}\mathrm{a}:-0.113, \mathrm{~b}: 0.003 \\
\mathrm{c}: 3.601\end{array}$ & 0.989 & 0.280 \\
\hline & 35 & $\begin{array}{c}\mathrm{a}:-0.0516, \mathrm{~b}: 0.003, \\
\mathrm{c}: 2.124\end{array}$ & 0.998 & 0.020 \\
\hline & 45 & $\begin{array}{c}\mathrm{a}:-0.0009, \mathrm{~b}: 0.002, \\
\mathrm{c}: 1.1091\end{array}$ & 0.981 & 1.911 \\
\hline \multirow[t]{4}{*}{ GAB } & 15 & $\begin{array}{c}\mathrm{c}: 1.000, \mathrm{k}: 53.382 \\
\mathrm{~m}_{0}:-3.997\end{array}$ & 0.682 & 15.494 \\
\hline & 25 & $\begin{array}{c}\mathrm{c}: 1.002, \mathrm{k}: 51.441 \\
\mathrm{~m}_{0}:-2.310\end{array}$ & 0.474 & 15.263 \\
\hline & 35 & $\begin{array}{c}\mathrm{c}: 1.000, \mathrm{k}: 51.779 \\
\mathrm{~m}_{0}:-2.580\end{array}$ & 0.700 & 66.610 \\
\hline & 45 & $\begin{array}{c}\mathrm{c}: 1.018, \mathrm{k}: 51.387 \\
\mathrm{~m}_{0}:-2.179\end{array}$ & 0.643 & 15.048 \\
\hline
\end{tabular}




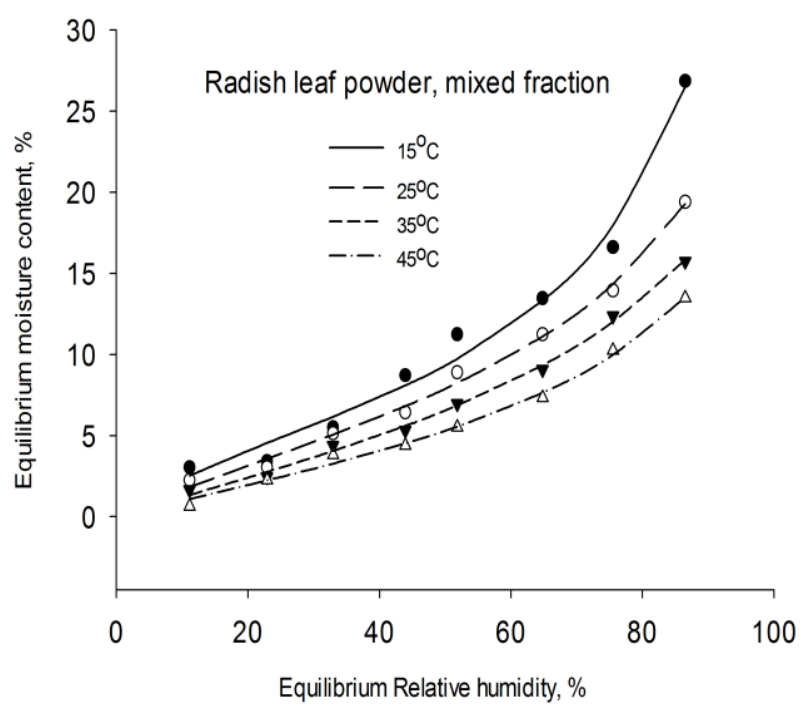

Figure 2. Temperature dependent adsorption isotherm of radish powder mix fraction

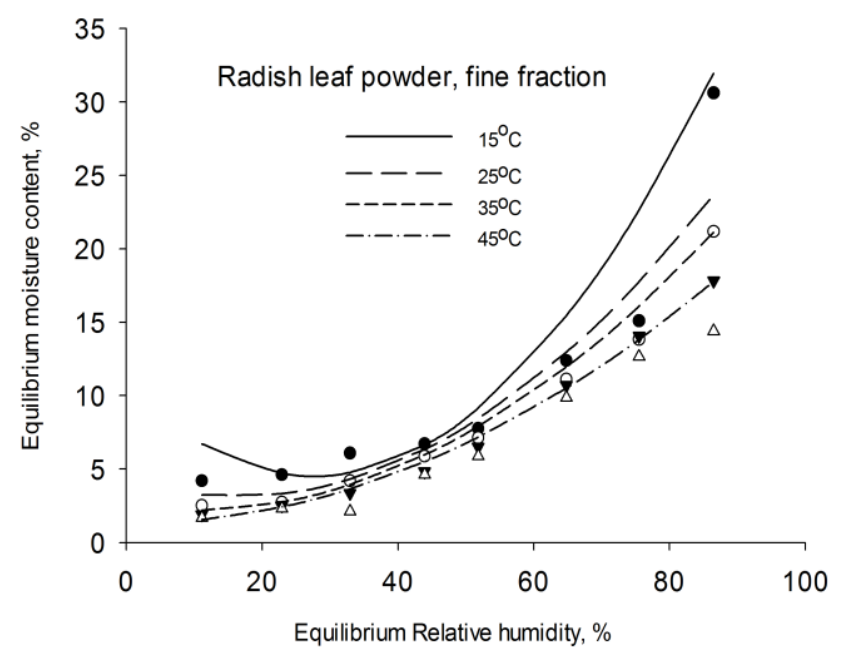

Figure 3. Temperature dependent adsorption isotherm of radish powder fine fraction

The isosteric heat of adsorption curve showed a regular fall with the increasing moisture content. Similar trend was seen for varieties of dates [27] for C. ambrosioides leaves [10] and for pistachio nut paste [21]. The higher heat of adsorption at lower moisture content can be justified because of the greater resistance to migration of water molecules from interior to the outer surface of the food samples [24, 28].

The value of heat of adsorption decreases approximately from 60.261 to $52.549 \mathrm{~kJ} / \mathrm{mol}$ and 54.004 to $43.540 \mathrm{~kJ} / \mathrm{mol}$ with the increasing equilibrium moisture content of mix fractions (MF) and fine fractions (FF) of radish leaf powder respectively. This reflects the differing strength of water binding molecules. In the beginning, initial occupation of highly active polar primary sites on the surface (with the greatest binding energy), followed by the subsequent filling of the less active secondary sites with lower bonding activation energies thus, lesser heat of adsorption. As the moisture content increases further, the heat of sorption or differential enthalpy tends to that of pure water which is a reflection of the moisture existing in the free form. Almost similar results were shown by previous researchers; isosteric heat of adsorption found $52 \mathrm{~kJ} / \mathrm{mol}$ with macroni powder [26] $48.54 \mathrm{~kJ} / \mathrm{mol}$ for instant tea powder and $47.96 \mathrm{~kJ} / \mathrm{mol}$ for tea granules [28], $85 \mathrm{~kJ} / \mathrm{mol}$ for potato powder, 58 $\mathrm{kJ} / \mathrm{mol}$ for amylose powder and $70 \mathrm{~kJ} / \mathrm{mol}$ for amylopectin powder [11].

Differential entropy of a food material is a function of the number of available sorption sites at a particular energy level. The graph between sorption entropy and equilibrium moisture content (figure 5) also gives the similar behavior as differential entropy decrease as the EMC increased [21]. The value of differential entropy decreases approximately from 43.564 to $43.556 \mathrm{~kJ} / \mathrm{mol} . \mathrm{K}$ and 43.559 to 43.532 $\mathrm{kJ} / \mathrm{mol} . \mathrm{K}$ with increasing EMC of mix fractions (MF) and fine fractions (FF) of radish leaf powder respectively. Almost similar results were shown by previous researchers; maximum value of differential entropy found $30 \mathrm{~kJ} / \mathrm{mol}$ for amylase powder, $60 \mathrm{~kJ} / \mathrm{mol}$ for amylopectin powder and $110 \mathrm{~kJ} / \mathrm{mol} . \mathrm{K}$ for potato starch powder [11].

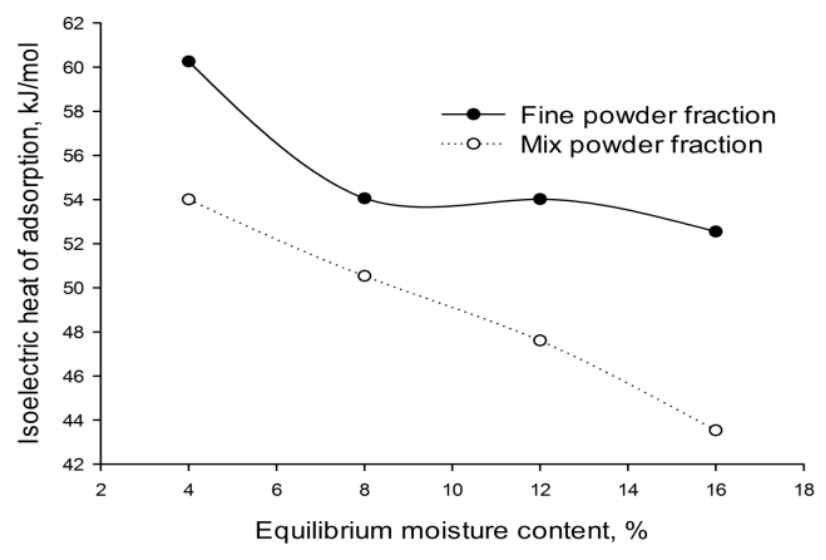

Figure 4. Isosteric heat of adsorption vs equilibrium moisture content of radish powder

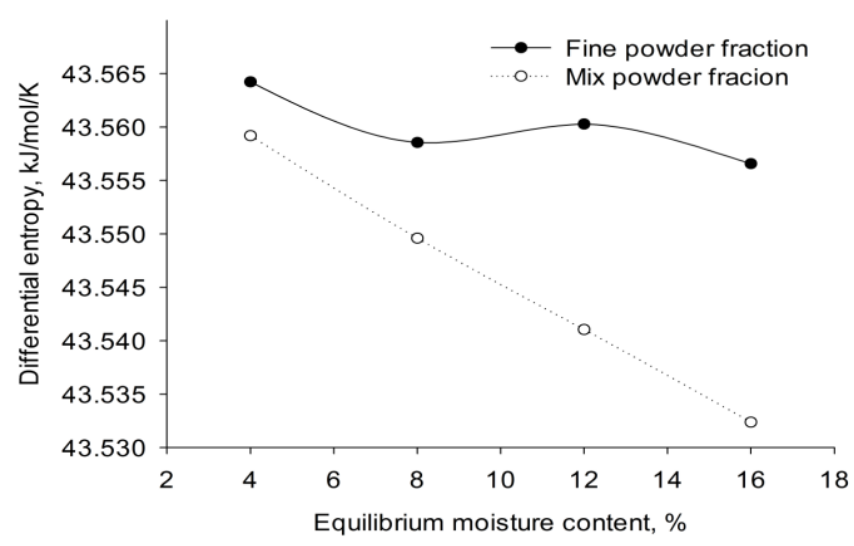

Figure 5. Differential entropy vs equilibrium moisture content of radish powder 
Gibb's free energy calculated at various temperatures and found that energy at higher temperature has given lower value and vice-versa. The value of free energy decreases approximately from 5.516 to $0.5251 \mathrm{~kJ} / \mathrm{mol}$ and 2.414 to $0.445 \mathrm{~kJ} / \mathrm{mol}$ with increasing EMC of mix fractions (MF) and fine fractions $(\mathrm{FF})$ of radish leaf powder respectively. It indicates the values of free energy are higher in case of fine radish leaf powder fractions. Free energy (figure 6) increases with decreasing moisture content [29].
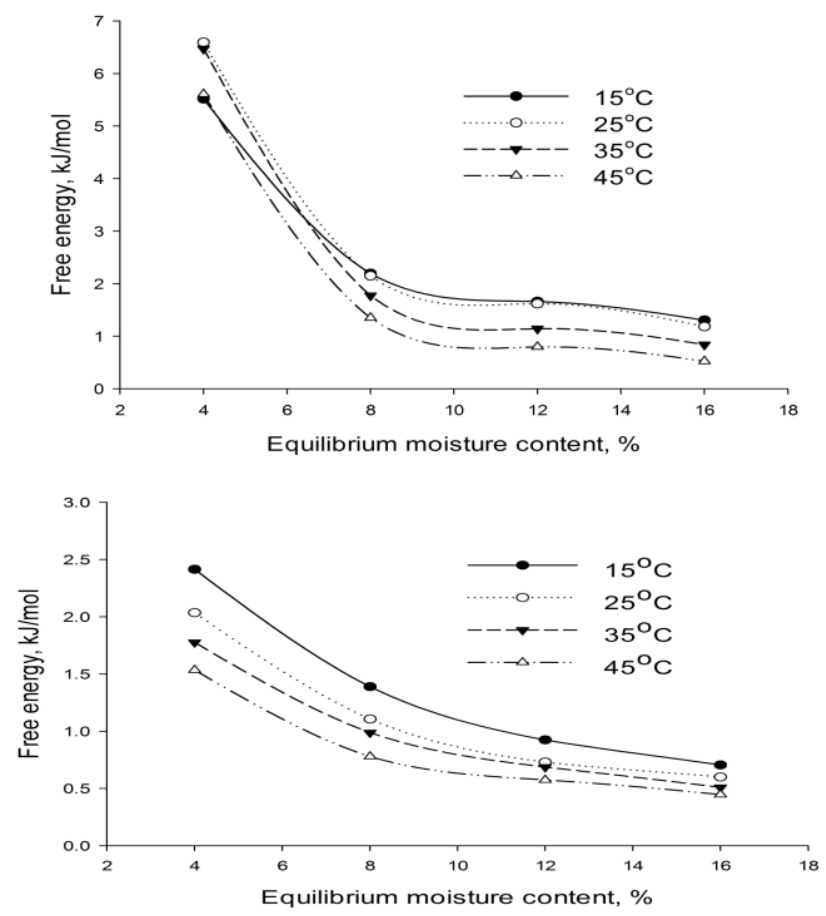

Figure 6. Free energy vs equilibrium moisture content of radish powder (Upper- fine fraction, Lower- Mix fraction

\section{Conclusion}

The experimental results showed that EMC values increased with decreasing temperature, at constant ERH. Equilibrium moisture content increases with the increase in the equilibrium relative humidity at constant temperature and show sigmoid change pattern. The adsorption data were in good agreement with most of popular sorption models. However, Polynomial and GAB equation could be found best in describing the adsorption isotherm at all the studied four temperatures for mix and fine radish leaf powder respectively. Almost similar trend of decreasing $\mathrm{m}_{0}$ values are reported in case of both fractions. The isosteric heat of sorption curve showed a regular decrease with increasing moisture content and the similar trend are observed for the sorption entropy and free energy.

\section{References}

1. R. M. P. Gutierrez, R. L. Perez, The Scientific World Jour., 4, 811 (2004)
2. M. Ngouajio, Oilseed Radish 48824 (2004)

3. K. A. Delahaut, A. C. Newenhouse, Growing carrots, beets, radishes and other crops in Wisconsin (1998)

4. S. Lim, E. J. Lee, J. Kim, Postharvest Biology and Technol., 100, 219 (2015)

5. H. L. Gohil, R. A. Bucklin, M. J. Correll, Advances in Space Research, 45, 823 (2010)

6. S. Herzallah, R. Holley, LWT - Food Science and Technology, 47, 293 (2012)

7. S. Sindhu, P. Maya, T. N. Indira, LWT - Food Science and Technology, 49, 42 (2012)

8. E. A. Noor, Materials Chemistry and Physics, 131,160 (2011)

9. P. Singh, J. Singh, International J. Plant, Animal and Environmental Sciences, 3, 103 (2013)

10. A. Jamali, M. Kouhila, L. Mohamed, J. Jaouhari, A. Idlimam N. Abdenouri, Journal of Food Engineering, 72, 77 (2006)

11. A. Al-Muhtaseb, W. McMinn T. Magee, J. Food Engg., 62, 135 (2004)

12. S. Kaya, T. Kahyaoglu, J. Food Engg., 71, 200 (2005)

13. Ankita, K. Prasad, Der Pharmacia Lettre, 7, 269 (2015b)

14. Ankita, K. Prasad, International Journal of Agriculture, Food Science and Technology, 3, 105 (2014b)

15. S. Ranganna, Handbook of Analysis and Quality Control of Fruit and Vegetable Products (1997)

16. M. Kouhila, A. Belghit, M. Daguenet, B. Boutaleb, J. Food Engg., 47, 281 (2001)

17. A. Cassini, L. Marczak, C. Noren, J. Food Engg., 77, 194 (2006)

18. M. Castillo, E. Martınez, H. Gonzalez, E. Pacin S. Resnik, J. Food Engg., 60, 343 (2003)

19. Heldman, Food dehydration, 446 (2004)

20. S. Lahsasni, M. Kouhila, M. Mahrouz, N. Kechaou, J. Food Engg.,55, 201 (2002)

21. M. Maskan F. Gogus, J. Food Engg., 33, 227 (1997)

22. L. Mohamed, M. Kouhila, A. Jamali, S. Lahsasni, M. Mahrouz, J. Food Engg., 67, 491 (2004)

23. N. Arslan, H. Togrul, J. Stored Pdts Res., 42, 112 (2006)

24. S. Kaya, T. Kahyaoglu, J. Food Engg., 78, 413 (2007)

25. D. S. Sogi, U. S. Shivhare, S. Garg, A. Bawa, Biosystems Engg., 84, 297 (2003)

26. N. Arslan, H. Togrul, J. Food Engg., 69, 133 (2005)

27. R. Myhara, S. Sablani, S. Al-Alawi, M. Taylor, LWT: Food Sci., 31, 699 (1998)

28. V. Sinija, H. Mishra, J. Food Engg., 86, 494 (2008)

29. I. Sawhney, Ph.D. Thesis, S.L.I.E.T (Deemed University), Longowal, India (2011) 